\title{
Space Debris: Legal and Policy Implications
}

\author{
Hakeem Ijaiya \\ Department of Private and Property Law, Faculty of Law, University of Ilorin, Nigeria. \\ Email: hakeemijaiya@gmail.com
}

\begin{abstract}
Today the greatest hazard facing human activities in outer space is space debris. These man-made objects orbiting Earth pose dangers to spacecraft and the astronaut alike. The study examines the sources of space debris, the risk posed by space debris to space activities and the outer space environment. The study also examines the effectiveness of the present legal mechanisms for the regulation of space refuse through an analysis of international legal policy with particular reference to the national space law and policy of the United States, European Union (EU), Russia and Japan. The study analyses the legal and policy implications of space debris in order to evaluate the adequacy of the present international legal regime for recognizing and regulating space debris. The study relies on primary and secondary sources of information. The information obtained through these sources was subjected to content analysis. The study concludes with a non-binding treaty-based proposal for a new legal debris control regime that can encourage compliance and enhance accountability. The study recommended a review of the international law as well as the laws and policies of international organizations and the major space-faring States.
\end{abstract}

Keywords: Debris, space debris, outer space, space environment, legal regime and legal policy.

\section{Introduction}

Since the commencement of space activities with the launch of the first artificial satellites and the development of rocket technology in the 1950s by the United State of America and the then Soviet Union ${ }^{1}$, a growing number of states have engaged in space activities, or intend to use space more intensively. Although these states do not have the capability to establish comprehensive space programmes similar to those of the space powers, some of them have at least set up space agencies in recent years. At present, more than fifty states have, to some extent, invested in domestic space activities, and the number of national space agencies is increasing steadily. Space activities are thus becoming less of a luxury and more of a necessity, as states increasingly regard them as an important political investment in the future. The socio-economic benefits of using outer space have also made the development of space programmes attractive to a number of developing states, including some in Africa. The potential adverse environmental effects of outer space activities are self-evident. Although there are a number of environmental problems related to space activities, the most prominent is the issue of orbital debris (space debris) ${ }^{2}$. This contribution highlights some uncertainties and lacunae in the

1 The Soviet Union launched the first space vehicle less than thirty-five years ago. Since then, the exploration and use of space have proliferated dramatically. Activities in space have generated millions of pounds of debris, most of it remaining in Earth orbit. This debris threatens the Earth's biosphere.

2 "Debris" is defined from the common English usage "debriser" which means to break down. In common English usage, "debris" means scattered fragments, wreckage or drifted accumulation. Therefore, strictly speaking, space debris includes only fragmentation debris and micro particulate matters. The terms "space debris" and "orbital debris" are used extensively in the academic and scientific literature concerning the impact of man-made space objects upon the space environment. Orbital debris is any man-made earth-orbiting object which is nonfunctional with no reasonable expectation of assuming or resuming its intended function or any other function for which it is or can be expected to be authorized. See David Tan, "Towards a New Regime for the Protection of Outer Space as the Province of All Mankind" (2000) 25 Yale J. Int'l L.145 at 151 Space debris ranges in size from fragments less than a millimetre in diameter to complete spacecraft many meters across. The nature of this 
current outer space treaty regime. It concludes that the current space treaties are largely outdated and inadequate to address the space debris problem. It is submitted that an international dialogue, involving the developed and the developing states, should be initiated as soon as possible in order to conclude a consolidated binding legal instrument for the regulation of all aspects concerning the use of outer space.

Outer space is becoming cluttered with litter. For nearly fifty years, states have been launching rockets into space, in orbit and Earth and beyond. The remains of derelict satellites and rockets and the debris resulting from their explosions and collisions are polluting the space environment. Space debris ranges in size from fragments less than a millimetre in diameter to complete spacecraft many meters across. The nature of this debris includes intact satellites, rocket bodies, fragments from exploded rocket bodies and fragments from collisions. Since late 1980s scientists and legal commentators have been calling states and international community to take action to prevent the effects of space debris ${ }^{3}$ on the environment. The latest estimate of space debris attributes $43 \%$ to China, $27.5 \%$ to the US and $25.5 \%$ to Russia[1] $]^{4}$. The sources of space debris include satellites that are no longer functional; mission related objects, such as tools lost by astronauts during extravehicular activities; and fragmentation events, which can be either accidental or intentional $[3]^{5}$. The research work explores the causes of orbital debris and examines the risk posed by debris to the orbital area. It also examines the environmental consequences of orbital debris and the legal control of debris. The work concludes with a non-binding treaty-based proposal for a new legal debris control regime that can encourage compliance and enhance accountability. The work recommended a review of the international law as well as the laws and policies of international organizations and the major space-faring States.

\section{Effects of Space Debris}

As the Earth moves around the sun, it encounters significant amounts of natural debris from comets, asteroids, dust and other sources. During collisions, this debris can degrade a satellite's solar panels, or if the debris is large enough, can penetrate into the interior of a spacecraft and destroy it $[6]^{6}$. Collision may result in loss of property or life, damage to persons or property. In 1983, the Challenger Windshield incident caused damages to spacecraft. In 1991, a non-functional Russian navigation satellite in CEO collided with a piece of debris that had previously detached from another Russian satellite. In 1996, a functional French spacecraft was hit by a fragment of a French rocket stage that had previously exploded ${ }^{7}$. Finally, in 2005 a US rocket and a fragment of a previously exploded Chinese rocket collided, creating several new pieces of tractable debris ${ }^{8}$. In 2009, an Iridium satellite collided with an inactive Russian Cosmos satellite. Objects resulting from these collisions are known as space debris $[2]^{9}$.

debris includes intact satellites, rocket bodies, fragments from exploded rocket bodies, fragments from collisions, and objects from extracurricular activities.

3 There are artificial debris and natural debris. Artificial debris is created by humans and is distinguished from natural debris such as meteoroids.

4 Ansdell, M “Active Space Debris Removal: Needs, Implications and Recommendations for Today's Geopolitical Environment" 2 June 2010 Princeton University 5 April, 2011 http://www.princeton.edu/ipia/past-issues$1 / 2010 /$ Space-Debris-Removalpdf

5 Jehn, R. (2008) "Introduction to the Problem of Space Debris" Lecture at the International Space University, Strasbourg, France, November 10, 2008

6 Taylor, M.W. Orbital Debris: Technical and Legal Issues and Solutions. Being LL.M Thesis submitted to the Institute of Air and Space Law, Mc Grill University, Montreal.

7 NASA Orbital Debris Program Office, "Accidental Collisions of Catalogued Satellites identified" (2005) 9:2 Orbital Debris Quarterly News 1 available at http://www.pdfs/ODQNv9i2. pdf.

8 Ibid.

9 David T. "Towards a New Regime for the Protection of Outer Space as the Province of All Mankind" (2000) 25 Yale J. Int'l L.145 at 151 


\section{$3 \quad$ Legal Control of Space Debris}

Current international and national laws and policies play important roles in limiting the creation of new orbital debris and in establishing liability for collisions caused by debris.

\subsection{International Space Laws}

International space laws have been created under the auspices of the UN Committee on the Peaceful Uses of Outer Space (COPUOS). To date, three treaties with potential relevance to orbital debris issues have entered into force:

- the Treaty on Principles Governing the Activities of States in the Exploration and Use of Outer Space, Including the Moon and Other Celestial Bodies, October 10, 1967 (the Outer Space Treaty);

- the Convention on International Liability for Damage Caused by Space Objects, September 1, 1972 (the Liability Convention); and

- the Convention on Registration of Objects Launched into Outer Space, September 15, 1976 (the Registration Convention).

\subsubsection{Outer-Space Treaty}

The fundamental treaty of space law- The Outer-Space Treaty ${ }^{10}$ - contains provisions to prevent the creation of orbital debris. Article IX declares:

In the exploration and use of outer space, including the moon and other celestial bodies, States Parties to the Treaty shall be guided by the principle of co-operation and mutual assistance and shall conduct all their activities in outer space...with due regard to the corresponding interests of all other States Parties to the Treaty. States Parties to the Treaty shall pursue studies of outer space, including the moon and other celestial bodies, and conduct exploration of them so as to avoid their harmful contamination... ${ }^{11}$

Article IX declares that States should consult with other States before engaging in activities which might cause "harmful interference" with the activities of the other States and that any State Party has the right to request consultations if it believes another States' activities have or will cause harmful interference $^{12}$.

The treaty creates obligation upon States to take reasonable measures to ensure that its activities do not interfere with the interests of other States or cause harmful contamination. Thus, a State which creates debris in the space environment would be said to be acting without due regard for the interests of other States, causing harmful contamination and is under a duty to consult.

There are two problems with this provision, however. First, it is impossible to operate in space without creating some amount of debris. The second problem is how to enforce and apply such an illdefined obligation. Without specific guidelines, one State would have difficulty proving that another State, by allowing debris to be created, had violated the due regard or harmful contamination clauses in Article IX ${ }^{13}$. Article IX at best encourages States to limit the generation of new orbital debris in a nonspecific manner, but there is little chance a State would ever be held internationally responsible for a violation of Article IX based upon creating ordinary debris $[6]^{14}$.

\subsubsection{Liability Convention}

State liability is also defined in Articles VI, VII and VIII of the Outer Space Treaty. Article VI makes a State internationally responsible for the activities of its non-governmental entities (such as individuals and corporations) occurring in outer space ${ }^{15}$. Non-governmental entities make up a substantial

10 Treaty Governing the Activities of States in the Exploration and Use of Outer Space, Including the Moon and Other Celestial Bodies, 27 January 1967, 610 UNTS 205, 18 UST 2410 (Outer Space Treaty)

11 Ibid. At Article IX

12 Ibid.

13 Nandasiri Jasentuliyana, " Celebrating Fifty Years of the Chicago Convention Twenty-Five Years After the Moon Landing: Lessons for Space Law", (1994) 19:2 Ann.Air \&Sp.L.429 at 442

14 Taylor, M.W. Orbital Debris: Technical and Legal Issues and Solutions. Being LL.M Thesis submitted to the Institute of Air and Space Law, Mc Grill University, Montreal.

15 Outer Space Treaty, Article VI 
proportion of space activity ${ }^{16}$ and are therefore the cause of a proportionate amount of orbital debris. Thus, through Article VI, State is directly responsible to other States for the consequences of orbital debris generated by non-governmental entities. The effect of Article VI is to apply the Corfu Channel ${ }^{17}$ and Trail Smelter ${ }^{18}$ principles to governmental and non-governmental activity in outer space

Article VII declares that:

Each State Party to the Treaty that launches or procures the launching of an object into outer space... and each State Party from whose territory or facility an object is launched, is internationally liable for damage to another State Party to the Treaty or to its nature or juridical persons by such object or its component parts of the Earth, in air or in outer space ${ }^{19}$.

Under the liability convention, a launching State is "absolutely liable" for damage on the surface of the Earth or to aircraft in flight. The Liability Convention explores the liability of states for damage caused by their space objects. The Article III of the Liability Convention makes states liable for damage "caused elsewhere than on the surface of the Earth to a space object of one launching state or to persons or property on board such a space object of another launching state ... only if the damage is due to its fault or the fault of persons for whom it is responsible." Article III of the liability convention, however, establishes a fault-based system for damage caused by a space object of one launching State to a space object (including persons and property on board) of another launching State of the damage occurred in space.

Article VIII declares that:

State Party to the Treaty on whose registry an object launched into outer space is carried shall retain jurisdiction and control over such object... while in outer space ${ }^{20}$.

The launching State has jurisdiction and control over space objects it launched. The Outer Space Treaty and the Liability Convention make a State liable for damage caused by any "object or its component Parts" that it launched into outer space ${ }^{21}$.

\subsubsection{Registration Convention}

The 1976 Convention on the Registration of Objects Launched into Outer Space, expands on the 1967 principle that nations retain jurisdiction over and responsibility for their facilities and objects in space. It mandates that a nation register its launch with a U.N. Registry, and thereby legitimate that nation's jurisdiction over the vessel or facility.

The Registration Convention seeks to provide information for use in determining liability by mandating that all launching states notify the UN of any objects they launch and provide the UN with the objects' orbital parameters. Article VI of the Registration Convention directs nations with monitoring or tracking facilities to aid in the identification of space objects that caused damage.

Other laws on mitigating space debris are:

The IADC Guidelines

16 For example, between 2001 and 2005, commercial launches into space account for 30 percent of the total number of launches.

17 The case arose out of the explosions of mines by which some British warship suffered damage while passing through the Corfu Channel in 1946 in a part of Albanian territorial waters which had been previously swept. The ships were severely damaged and members of the crew were killed. The International Court of Justice found that Albania was responsible under international law for the explosions, damage, and loss of life in Albanian water

18 From approximately 1925 to 1937, an ore smelting plant in British Columbia, Canada created tons of sulphur dioxide fumes. The fumes caused significant environmental damage to the State of Washington, for which the US Government sought and was awarded compensation from Canada.

19 Outer Space Treaty, Article VII. However, there is a terrifying large legal gap when it comes to disputing resolution and compensation mechanisms. The issue of liability protocols in case of commercial disruption by debris is also not covered by any convention.

20 Ibid at Article VIII

21 Ibid at Article VII 
The IADC was formed in 1993 as an international forum to harmonise the efforts of various space agencies to address the problem caused by orbital debris ${ }^{22}$.

(ii) The COPUOS Space Debris Mitigation Guidelines

In 1959, the UN General Assembly established the Committee on the Peaceful Uses of the Outer Space (COPUOS) as a permanent body to maintain close contact with governmental and non-governmental organisations concerned with outer space matters, to provide for the exchange of such information relating to outer space activities as supplied by the states on a voluntary basis, and to assist in the study of measures for the promotion of international cooperation in outer space activities ${ }^{23}$.

(iii) Basic Concept of Space Traffic Management

The 1969 OST contains a set of principles, a number of which are of direct relevance to space traffic.

(iv) The Draft International Code of Conduct for Outer Space Activities of the European Union.

The EU initiative for an International Code of Conduct ( $\mathrm{CoC}$ ) for space activities was launched at the end of 2008 as a means to achieve enhanced safety and security in the outer space through the development and implementation of transparency and confidence-building measures.

(v) The Long Term Sustainability of Space Activities

The Long Term Sustainability of space activities (LTSSA) is an initiative under UNCOPUOS tasked with producing a consensus report outlining voluntary best practice guidelines for all space actors to ensure the long-term sustainable use of outer space.

(vi) The Group of Governmental Experts of the UN.

The Group of Governmental Experts (GGE) on Transparency and confidence-building measures (TCBMs) in outer space Activities is a UN initiative.

\subsection{National and Regional Policies on Space Debris}

Several national and international organisations of the space faring nations, including United States, European Union (EU), Russia and Japan have engaged in developing technically feasible and practical ways and means of decreasing or avoiding space debris.

\subsubsection{The United States Debris Mitigation}

The United States has long been concerned about the impact of orbital debris on the space environment and has developed a series of technical and policy based solutions. To actualize this, it created an agency known as NASA ${ }^{24}$. As early as 1981, NASA initiated a 10-year assessment plan for orbital debris. The purpose of the plan was to begin the process for US policies and eventually international agreements on orbital debris.

In 1987, the US Government created the Department of Defence (DoD) which addresses debris issues for the first time in its official space policy. The DoD was the first US Government agency to create a written orbital debris policy.

In 1988, formal President Ronald Reagan of US issued a Presidential Directive on US National Space Policy and also called for all space sectors to minimize debris consistent with mission requirements and

22 As at 2013, the IADC comprised ASI (Agenzia Spaziala Italiana, Italy), BNSC (British National Space Centre), CNES (Centre national d'etudes spatiales, France), CNSA (China National Space Administration), CSA (Canadian Space Agency), DLR (German Aerospace Center), ISRO (Indian Space Research Organisation), JAXA (Japan Aerospace Federal Space Agency), NSAU (National Space Agency of Ukraine), and Roscosmos (Russian Federal Space Agency)

23 Today, COPUOS has 74 members.

24 Other US agencies are National Oceanic and Atmospheric Administration (NOAA), Federal Communications Commission (FCC) and Department of Transportation (DOT) 
cost effectiveness. President Reagan policy states that "all space sectors will seek to minimize the creation of space debris...consistent with mission requirements and cost effectiveness."

In 1989, the US Government issued a report and a congregational background paper in 1990 on orbital debris. Following these reports, NASA began measuring orbital debris with computer simulations. NASA also entered into bilateral discussions with the space agencies of other major space-faring States, which led to the creation of the Interagency Space Debris Coordination Committee (IADC). Another U.S. initiative is NASA's "Space Debris Handbook," which may become an important technical reference for space debris reduction measures ${ }^{25}$.

NASA was the first space agency to issue a comprehensive set of orbital debris mitigation guidelines in 1995.

In 1996, the former President Bill Clinton issued the latest version of the US National Space Policy. The police states:

The United States will seek to minimize the creation of space debris. NASA, the intelligence community, and DoD, in cooperation with the private sector, will develop and design guidelines for future Government procurements of spacecraft, launch vehicles, and services. The design and operation of space texts, experiments, and systems will minimize or reduce accumulation of space debris consistent with mission requirements and cost-effectiveness.

NASA and DoD are responsible for creating its own specific policies on orbital debris in order to achieve the goal of minimizing the creation of debris $[5]^{26}$.

The current NASA policy states that it will "limit the generation of orbital debris...consistent with mission requirements and cost effectiveness" ${ }^{27}$. To accomplish this objective, the NASA policy requires a review of each spacecraft to assess its debris creating potential ${ }^{28}$. This policy is also implemented by a NASA Safety Standard ${ }^{29}$. The Safety Standard requires assessments for debris generated during normal operation; debris created by accidental explosions and intentional breakups; debris resulting from nonorbit collisions; and safe disposal options for spacecraft at the end of their useful life ${ }^{30}$.

The DoD has directed that debris should be minimized, consistent with mission requirements and cost effectiveness ${ }^{31}$. Furthermore, it also directed that at the end of a spacecraft's mission, debris should be removed from space or replaced in storage orbit ${ }^{32}$. Also DoD instruction declares that debris mitigation must be taken into account when purchasing and operating spacecraft ${ }^{33}$.

In 2000 the US government issued formal orbital debris mitigation standards for space operators developed by the DoD and NASA (United States Government Orbital Debris Mitigation Standard Practices). The US Federal Communications Commission (FCC) rules 2004 required satellite operators to move geostationary satellites at the end of their lifetime into graveyard orbits 200 to $300 \mathrm{~km}$ above GEO, and new rules in 2005 required satellite system operators to submit orbital mitigation plans.

Other US agencies are the National Oceanic and Atmospheric Administration (NOAA) ${ }^{34}$, Federal Communication Commission (FCC) ${ }^{35}$ and Department of Transportation (DOT) ${ }^{36}$.

25 This Handbook is consistent with the objectives of the US National Space Policy (August 2006), the US Government Orbital Debris Mitigation Standard Practices (February 2001), the IADC Space Debris Mitigation Guidelines (October 2002), and the Space debris mitigation guidelines of the STSC of the UNCOPUOS.

${ }^{26}$ Michael, W.T. (2006) Orbital Debris: Technical and Legal Issues and Solutions. Being LL.M Thesis, Mc. Gill University, Montreal.

27 NASA Policy Directive 8710.3B, NASA Policy for Limiting Orbital Debris Generation (27 January 2003) at para 1

28 Ibid.

29 NASA Safety Standard 1740,14 Guidelines and Assessment Procedures for Limiting Orbital Debris (August 1995)

30 Ibid.

31 Department of Defence Directive 3100.10 Space Policy (9 July 1999) at paras 4.11.5, 4.11.6

32 Ibid.

33 Department of Defence Instruction 3100.12, Space Support (14 September 2000)

34 NOAA is responsible for licensing commercial remote sensing satellite systems

35 FCC is responsible for licensing commercial communications satellites

36 DOT licenses space launch vehicles 


\subsubsection{European Space Agency}

The European Space Agency (ESA) operates a Network of Centres that work together to coordinate orbital debris efforts in Europe ${ }^{37}$. The ESA concern with orbital debris dates back to 1986 when a task force was formed to study the issue and published a report in $1988^{38}$. In 1989 ESA's Council passed a resolution defining the agency's objectives in the field of space debris. ESA's policy is "...to reduce to the maximum possible extent the production of space debris and to promote exchange of information and cooperation with other space operators..." The ESA's work culminated in a 2004 European Code of Conduct for Debris Mitigation ${ }^{39}$. The European Code consists of twelve design guidelines and eight operational guidelines that all ESA members should follow in order to mitigate orbital debris. Each of the guidelines falls into one of four categories: prevention, end-of-life, impact protection, and re-entry safety measures ${ }^{40}$.

\subsubsection{Russia}

The Russian Federation also has a policy on debris, alluded to in Section I, Article 4, Paragraph 2 of its Law on Space: "For the purpose of ensuring strategic and ecological safety in the Russian Federation, the following are forbidden: harmful pollution of space, leading to unfavourable environmental changes, including intentional destruction of space objects in space." In 2000, Russia put into force a "General Requirements for Mitigation of Space Debris Population". The requirements in this standard are consistent with those of other agencies within the IADC. Russia has in place a Space Debris Mitigation Standard, which again follows the IADC guidelines.

\subsubsection{Japan}

The National Space Development Agency (NASDA) of Japan first adopted a Space Debris Mitigation Standard in March 1996. The Standard addresses all of the pertinent debris issues, such as collisions, released debris, and maintenance of the GEO belt. The Standard was updated in 2003 to align more closely with the IADC standard.

\section{Obstacles to Space Debris Legal Regimes and Policies}

The current legal regime governing objects in space was developed long before orbital debris was considered to pose any hazard. Thus, no legal rules are specifically designed to ameliorate the threats presented by orbital debris that presently exists. The most that can be said is that the existing international law permits States to implement debris mitigation measures. It is, in fact, the lacunae concerning orbital debris in international law are satellite registration, protection of the space environment, liability convention, remediation and mandatory technical regulations.

The UN treaties deal with some of the issues raised by the presence of orbital debris, while many other debris-related issues are not addressed. For example, the treaties do not address the potential need for measures to reduce the creation of new debris. (The only reference that may be applicable is Article IX of the Outer Space Treaty, which calls for "consultations" if member states believe activities or experiments would cause potentially harmful interference with other space activities.) In addition, some of the issues that are raised in the treaties are difficult to apply to debris. For example, the liability convention assigns liability based on ownership of the objects involved. Even where the treaties may be applicable to debris issues, interpretation is often difficult because the legal definitions of "space debris" and "space objects" are not entirely clear.

There is a critical weakness in the international law on space debris. Existing space law is related to the use of space and not to debris regulation. Most existing treaties have been overtaken by technology advancement. While the rules system developed by the Outer Space Treaty or the Registration

37 The network includes four space agencies: the British National Space Centre (BNSC), CNES of France, the German Aerospace Centre ( DLR) and ESA.

38 European Space Agency, European Space Operations Centre: Focal Point for ESA Space Debris Activities. Available at http://www.esa.int/SPECIALS/SEMU2CW4QWD_O.HTM1

39 European Code of Conduct for Debris Mitigation, Issue 1.0, 2004. Available at hpp://www.stimon.org/wos/pdf/eurocode.pdf.

40 Ibid 
Convention is useful, it does not apply to space debris issues. This means that commercial and government-sponsored space launches can still create more debris without limits

The problem of existing space debris mitigation guidelines is troubling. A few space agencies and governments have adopted mitigation guidelines. In February 2007, the UN reached a consensus on the draft of space debris mitigation guidelines and adopted them. However, all of the existing guidelines remain voluntary and are not legally binding under international law.

\section{Conclusion}

The current efforts to address space debris ignore the applicability of the Liability Convention. The perception seems to be that the Liability Convention is so lacking in specificity that it cannot be used to address space debris. It is suggested that the recently enacted Optional Rules for Arbitration of Outer Space Activities could be used to clarify the short-comings of the Liability Convention instead of discarding it completely.

Liability Convention and other Space Treaties, no doubt were made for the best of mankind but analyzing the amount of risk, the Space Debris is posing to the future of mankind. It is necessary to solve the existing problems and find more rational solutions. This problem requires all nations to agree on some universal measures, with international cooperation. All countries must focus on PDD (Planning, Drafting and then Developing) method.

The current lacuna of international law concerning orbital debris needs to be filled with enforceable rules and definitions that provide certainty and accountability $[4]^{41}$.

Efforts should be made toward promoting the activities that may influence orbital debris regulations. A number of activities outside the UN may affect future laws and policies on orbital debris issues. These include efforts by such organizations as the International Telecommunication Union, the IAA ${ }^{42}$, the International Law Association ${ }^{43}$, the IADC ${ }^{44}$, and others.

The international community, particularly the established space actors should engage in discourse for developing State practice and legal and policy guidelines on space debris remediation.

41 Nandasiri Celebrating Fifty Years of the Chicago Convention Twenty-Five Years After the Moon Landing: Lessons for Space Law", (1994) 19:2 Ann. Air \&Sp.L.429 at 442J. "

42 The IAA issued a "Position Paper on Orbital Debris" in October of 1993. This paper was written by an Ad hoc Expert Group of the IAA's Committee on Safety, Rescue, and Quality, and was reviewed by that committee and by members of other IAA committees and of the International Institute of Space Law before being approved by the IAA board of trustees and published in Acta Astronautica. The position paper contains a brief technical discussion of the present and future debris situation and suggests a number of debris control measures ranked by priority. As the output of an international body of debris experts, this paper may influence future regulations on orbital debris.

43 The Space Law Committee of the ILA has studied legal aspects of orbital debris since 1986. In August 1994, the ILA adopted (in a resolution) a draft "International Instrument on the Protection of the Environment from Damage Caused by Space Debris." This instrument, structured in 16 articles, is the first legal text on space debris agreed to by an international body. It contains a definition of space debris, describes the general obligation of states and international organizations to cooperate (inform, consult, and negotiate in good faith) in the prevention of damage to the space environment. Although this instrument does not constitute law or policy and does not address the technical means to reduce the creation of orbital debris, it could potentially serve as a first step in moving the debris issue into the legal regime.

44 Interagency orbital debris coordination meetings involving the ESA, the Russian Space Agency, NASA, and the space agencies of Japan are held biannually. Though these meetings do not deal with the legal aspects of the orbital debris issue, the technical issues of space debris measuring, modelling, and reduction techniques are discussed in detail. Since the four attending space agencies are involved in the majority of all space activities, these meetings represent the biggest forum of practical expertise in the field, and may help to provide the sound technical background needed for the development of any new legal rules on debris. 


\section{References}

1. Ansdell, M “Active Space Debris Removal: Needs, Implications and Recommendations for Today's Geopolitical Environment" 2 June 2010 Princeton University 5 April, 2011

2. David T. "Towards a New Regime for the Protection of Outer Space as the Province of All Mankind" (2000) 25 Yale J. Int'l L.145 at 151

3. Jehn, R. (2008) "Introduction to the Problem of Space Debris" Lecture at the International Space University, Strasbourg, France, November 10, 2008

4. Nandasiri J. " Celebrating Fifty Years of the Chicago Convention Twenty-Five Years After the Moon Landing: Lessons for Space Law", (1994) 19:2 Ann. Air \&Sp.L.429 at 442

5. Michael, W.T. (2006) Orbital Debris: Technical and Legal Issues and Solutions. Being LL.M Thesis, Mc. Gill University, Montreal.

6. Taylor, M.W. D : Technical and Legal Issues and Solutions. Being LL.M Thesis submitted to the Institute of Air and Space Law, Mc Grill University, Montreal. Orbital 